\title{
Wildmeat or Bushmeat? Subsistence Hunting and Commercial Harvesting in Papua (West New Guinea), Indonesia
}

\author{
Margaretha Pangau-Adam • Richard Noske • \\ Michael Muehlenberg
}

Published online: 5 May 2012

(C) The Author(s) 2012. This article is published with open access at Springerlink.com

\begin{abstract}
It is well known that wild game provides a significant proportion of the dietary protein of the indigenous people of the eastern half of New Guinea (PNG), but almost nothing is known of its importance in the western half (the Indonesian province of Papua or Irian Jaya). We quantified hunting effort, harvest rates and wild meat consumption and sale in the Jayapura region of north-east Papua through interviews with 147 hunters from 21 villages and meal surveys in 93 households. Ten species of mammals, seven species of birds and at least two species of reptiles were harvested in our study area, but the introduced wild pig and rusa deer were the major target species. Hunting in our study area has shifted from a purely subsistence activity towards a more commercial form at least partly due to the emergence
\end{abstract}

\footnotetext{
M. Muehlenberg

Department of Conservation Biology, Institute of Zoology and Anthropology, Georg-August University of Goettingen,

Buergerstrasse 50,

37073 Goettingen, Germany

\section{Pangau-Adam}

Biology Department, Faculty of Natural Sciences and

Mathematics, Cenderawasih University,

Papua, Indonesia

\section{R. Noske}

Research Institute for the Environment and Livelihoods, Charles Darwin University,

Darwin, Northern Territory, Australia

Present Address:

M. Pangau-Adam ( $\varangle)$

Department of Conservation Biology, Institute of Zoology and

Anthropology, Georg-August University of Goettingen,

Buergerstrasse 50,

37073 Goettingen, Germany

e-mail: mpangau1@uni-goettingen.de
}

of markets created by Indonesian transmigrants. Although the hunting of non-indigenous and certain native species might be sustainable, the maintenance of populations of large threatened species will require sensitive management.

Keywords Wildmeat - Bushmeat · Rusa deer - Sustainable hunting · Tropical forests · Threatened species · Irian Jaya · Papua Indonesia

\section{Introduction}

Hunting by indigenous peoples is no longer sustainable in many tropical forest regions (Robinson and Redford 1991; Bennett and Dahaban 1995; Alvard et al. 1997; Robinson and Bennett 2000). Increased human population growth, improved hunting techniques, greater accessibility to forest interiors and increased economic benefits inevitably lead to increased hunting pressure and therefore local if not regional declines in wildlife populations (Bennett et al. 2000; Wilkie et al. 2000). In the vast tropical rainforests of New Guinea, the world's second largest island, the hunting of wildlife has traditionally been one of the most important livelihood activities of indigenous people because it provides most of a family's animal protein (Petocz 1989; Dwyer and Minnegal 1991; Sillitoe 2001; Mack and West 2005). Moreover, wildlife is important culturally since various animal parts are used as adornments in ceremonies or as ornaments (e.g., feathers and fur) and tools (e.g., bones and teeth) in daily life (Majnep and Bulmer 1977; Frith and Beehler 1998). In addition, certain animals are part of the traditional belief systems of many ethnic groups (Majnep and Bulmer 1977, 2007; Kwapena 1984; Healey 1989, 1993).

Whilst there have been many studies of hunting in New Guinea (see Cuthbert 2010 for summary), most are from an anthropological perspective. Few have considered the 
sustainability of hunting practices, yet in the eastern half of the island (Papua-New Guinea) alone, the number of wild vertebrate animals killed for domestic consumption is estimated to be between 4 and 8 million (Mack and West 2005). New Guinea differs from other tropical rainforest regions of the world in having few large native game species, the largest being the flightless cassowaries (Casuariidae; 25-60 kg). As these few large animals provide the highest protein reward, they are usually the first to be extirpated from forests close to villages (e.g., King and Nijboer 1994; BirdLife International 2000; Richards and Suryadi 2000). Indeed fossil evidence suggests that hunting has contributed to the local extinction of several species of larger mammals in New Guinea in the past (Flannery 1994).

Recent analyses of hunting and capture rates, combined with estimates of population densities and rates of increase, have shown that offtake rates of cassowaries and several frequently killed medium-sized mammals are unsustainable (Johnson et al. 2004; Cuthbert 2010). Not surprisingly, 11 of the 14 species of tree-kangaroos (Dendrolagus spp.), most of them endemic to New Guinea, and two of the three cassowaries, are now considered threatened with, or vulnerable to, extinction, principally due to hunting (Stattersfield et al. 1998; IUCN 2010). To date, however, studies of hunting practices in New Guinea have been largely confined to the eastern half of the island, where there is little or no market for "bushmeat" or trade in wildlife (Mack and West 2005; Cuthbert 2010).

The Indonesian province of Papua (formerly Irian Jaya) covers the western half of New Guinea, and with a total land area of $416,129 \mathrm{~km}^{2}$, is the nation's largest province. Although hunting of wildlife in Papua is not prohibited, the Indonesia government has ratified laws for the protection of certain species of fauna (Government Regulation PP No. 7 1999). Most villagers are unaware of these regulations. Moreover, a lack of adequate monitoring and enforcement by the government, and the need to make a livelihood and carry out traditional customs, local people still hunt and trade wild animals, including many 'protected' species, in both 'protected' and non-protected (Suryadi et al. 2007; Pangau-Adam and Noske 2010).

Profound social changes over the last two decades (Timmer 2007) have dramatically altered hunting pressure and market demand for animal products in Papua. Rapid development and improved infrastructure have enabled hunters from remote villages to offer their harvest in the markets, and increased numbers of vehicles have accelerated the transport of harvested animals to market towns. In addition immigrant communities of non-indigenous people, spawned by past Indonesian transmigration programmes, have created regional, national and even international markets for the exploitation of local natural resources. Hunting is thus gradually moving away from a purely subsistence towards a commercial form. Commercial harvesting of wildlife thus threatens the traditional life-styles of indigenous populations, through the weakening or loss of traditional laws and taboos (Kwapena 1984).

The aim of the current study was to expand our knowledge of indigenous hunting practices in New Guinea by quantifying its extent among villagers in the Jayapura region of northeast Papua, Indonesia, where no such studies have been undertaken to date. We designed surveys to quantify hunting effort and techniques, harvest rates of target species, and the motivations for hunting. We also conducted meal surveys to determine the level of consumption of wild meat and other food items, and monitored two local markets to measure the extent of bushmeat trade using these data. We consider whether current wildlife extraction rates might be a cause for concern in this part of New Guinea. As the hunting and trade of birds from these villages has been described elsewhere (Pangau-Adam and Noske 2010), this paper focuses on the exploitation of mammals and reptiles. Following Mack and West (2005) we use the terms 'wildmeat' and 'bushmeat' to distinguish between wild animals killed for consumption by the hunter and his family, and those that are killed to generate income, respectively.

\section{Study Area and Methods}

Our study area was located about $110 \mathrm{~km}$ west of Jayapura, the capital city of Papua, Indonesia. Although forests around the villages had been cleared for agriculture, large primary forest areas remained. Roads and trails provided access into the forest. At an elevation ranging from 50 to $200 \mathrm{~m}$ above sea level, the vegetation of the study area was humid (lowland) tropical rainforest subject to inundation (Conservation International CI 1999). Typical canopy tree genera were Ficus, Pometia, Intsia, Canarium, Alstonia and Terminalia, while understory trees included Myristica, Syzygium, Garcinia, Diospyros, Pandanus and palms, including rattans. Ethnically, most of the local people in this area belong to the Genyem group. They are divided into several clans, each of which owns one or more forest blocks, as almost all land in Papua is claimed as a land right of a tribe.

Surveys were conducted each month from July 2005 to June 2006 at two forest sites in each of two districts (Nimboran and Kemtukgresi) of the Jayapura region (Fig. 1). Nimboran district $\left(660 \mathrm{~km}^{2}\right)$ contained 14 villages, including two transmigration villages, with a total of 4,329 inhabitants, and included two areas of partly logged lowland rainforest on relatively flat land crossed by several roads made by the loggers. These forests provided accessible bird watching sites for international bird watching groups. Kemtukgresi district $\left(625 \mathrm{~km}^{2}\right)$ had a similar population with 3,752 inhabitants living among 11 villages, but there was no transmigration village, and the forest was in hilly terrain, used little by loggers or birdwatchers. Nimboran district also supported the large trading town of Genyem, and most 

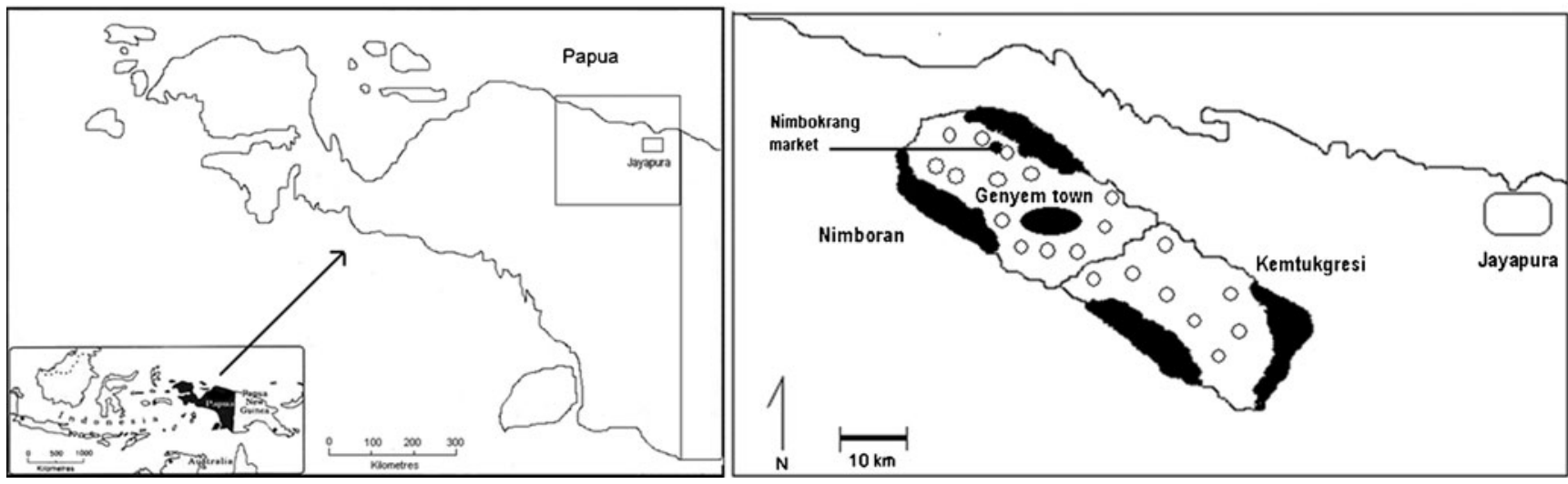

Fig. 1 Map of Papua (left) and study sites in north-east Papua (right). Dots represent sample villages in Nimboran ( $n=13)$ and Kemtukgresi district. $(n=8)$; black areas represent forest sites $(n=2$ in each district)

villages sampled in this district were closer $(1-15 \mathrm{~km})$ to this town than those in Kemtukgresi district (10-30 km) (Fig. 1). We predicted that the level of trade in game animals (bushmeat) would be higher in Nimboran villages due to their closer proximity to this trading town.

Hunting data were collected through interviews, structured questionnaires, and hunting surveys in 13 villages in Nimboran district, and eight villages in Kemtukgresi district. Village or community leaders were first approached and interviewed to obtain general information on the number of households engaged in hunting practices. Semistructured interviews were then conducted with the hunters at their households or in c. $20 \%$ of cases, on their way home from hunting sites. A total of 147 hunters (84 in Nimboran and 63 in Kemtukgresi) were interviewed using a set of questions designed to quantify hunting effort and techniques, species harvest rates, and the motivations for hunting.

Each hunter was asked: (1) the duration of all hunting trips during the last month, (2) hunting group size, (3) distance traveled to hunting sites, (4) types and number of weapons and/or traps used, (5) number and species of animals harvested in the last month, and (6) the intended use of captured animals (subsistence or commercial). Recently killed animals were weighed with standardized scales and identified using field guides (Beehler et al. 1986; Menzies 1991; Flannery 1995). Hunters were also asked about their perception of population trends among the most frequently targeted species. The annual off-take for each village was calculated by adding the monthly animal kills reported by hunters for the entire year. Wild meat off-take by weight was calculated by multiplying the number of animals reportedly killed each year by the average body weight for each species concerned (sourced from Beehler et al. 1986; Menzies 1991; Flannery 1995).

Household meal surveys were conducted to determine the level of consumption of wild meat and other food items (i.e., livestock meat, fish, vegetables). These surveys consisted of interviews with housewives in 93 households among four villages $(n=56)$ in Nimboran and three in Kemtukgresi $(n=37)$. Each housewife was asked about the kinds of meals they prepared during a one-week period. All respondents identified themselves as belonging to the Genyem ethnic group.

In addition two local markets in Genyem and Nimbokrang were monitored each week to measure the regularity and extent of wildlife trade. Informal discussions were conducted with 33 vendors to identify the species being sold, their source, weight, price, and demand from buyers.

\section{Results}

All villagers consumed wild meat killed by hunters at least occasionally, especially at ceremonial events, and traditionally, each animal killed was shared by all family or clan members, or even all villagers, if the village was small. Yet only $15-20 \%$ of villagers were actively involved in hunting. All hunters were male, ranging in age from 16 to 69 years old, and almost all village leaders were part-time hunters. Approximately $60 \%$ of the 147 hunters interviewed identified themselves as professional hunters who also farmed (56\% and $49 \%$ in Nimboran and Kemtukgresi, respectively), as opposed to $37 \%$ (19 \% in Nimboran and $36.5 \%$ in Kemtukgresi) who indicated that farming was their main profession and hunting a part-time activity only. Full-time hunters were rarely encountered (3\%) in our study area. The stated reason for hunting was overwhelmingly for commercial gain. Only $5 \%$ of hunters in Nimboran (including the market town of Genyem), and $38 \%$ of those in Kemtukgresi, declared that they hunted primarily for subsistence.

Hunting Techniques

Several different hunting techniques were practised and each hunter typically used more than one technique. The 
most widely used techniques were snare trapping and archery (Table 1). Foot snares rely on an animal falling into a small concealed pit, which triggers the release of a bent sapling that causes a nylon or wire noose to grip tightly around the animal's leg. Bush or forest materials were used to trap small marsupials (e.g., bandicoots) and grounddwelling birds. Captured animals often suffer a painful death, as most animals struggle violently to free themselves, often breaking limbs and dying slowly of shock, blood loss, exhaustion and starvation. Animals occasionally escape by severing a foot or by breaking the snare. Snares are nonselective with respect to species, age or sex of targeted animals, but they can be selective in regards to the size of an animal. Large snares were set to capture wild pigs, rusa deer, cassowaries and wallabies, while smaller ones were set for trapping bandicoots, and large ground-dwelling birds such as Crowned Pigeons and megapodes (Megapodiidae). Some hunters checked their snare lines only twice a week, but most checked them every other day. Hunters reported that wild pigs can survive up to a week in snares, but cassowaries could not survive more than 3 days.

Along with catapults, air rifles were used for killing or capturing flying foxes and arboreal marsupials, as well as birds of paradise. Hunting with dog and a spear was mainly used to catch White-striped Wallabies, wild pig and rusa deer. In both districts, some hunters also hunted at night using flashlights and spears. Cuscuses and tree kangaroos were occasionally caught during the day by felling trees.

\section{Hunting Practices}

Hunting is mostly practised alone. However, when they need to hunt animals for community festivals and religious ceremonies, the members of a clan group may hunt together. In our area, hunting sites corresponded to "clan forests", which included secondary forest and primary forest, as well as mixed gardens. A total of 26 and 18 hunting sites were identified in Nimboran and Kemtukgresi, respectively. Habitats used for hunting varied from mixed gardens near villages to the deep interior of primary forest.

Table 1 The frequency (\%) of use of various hunting techniques on each hunting trip. Percentages do not add to 100 because two or more techniques were typically used by each hunter on most hunting trips. Dogs were used with the other techniques like spear and snare

\begin{tabular}{lll}
\hline Technique & Nimboran $(n=84)$ & Kemtukgresi $(n=63)$ \\
\hline Bow and arrow & 92 & 98 \\
Snare & 88 & 71 \\
With dog & 21 & 19 \\
Air rifle & 5 & 17 \\
Spear & 10 & 4 \\
\hline
\end{tabular}

The distance travelled from village to hunting sites ranged from $2 \mathrm{~km}$ to $16 \mathrm{~km}$, and as expected, differed between the two districts. Hunters from villages in Kemtukgresi made more medium-distance hunting trips $(5-10 \mathrm{~km})$ than those from Nimboran (Fig. 2). The mean distances to hunting sites in Nimboran and Kemtukgresi was $4.4 \mathrm{~km}$ and $7.4 \mathrm{~km}$, respectively, and the difference was significant $\mathrm{t}=-$ $6,8, \mathrm{df}=145, p<0.01$ ) (Fig. 2). Accordingly, the amount of time devoted to hunting was significantly longer for hunters from Kemtukgresi than for those from Nimboran $(t=4.05$, $\mathrm{df}=73, p<0.01$ ), with an average (and maximum) of 19.6 (48) and 12.7 (35) hours per week, respectively, in these villages (Fig. 3). Several hunters mentioned that hunting activity decreased during the rainy season (October-February), because of low visibility, decreased animal activity during heavy rains, and reduced access to sites due to flooded rivers. In villages with farms, some hunters turned to clearing, burning and planting during this time of the year.

Target Animals

Of the 12 non-avian hunted taxa that were identified, ten were mammals and two were reptiles (Table 2). Five of the mammal species have putative 'protected' status under Indonesian law for Natural Resources and Ecosystems (Government Regulation PP No. 7 1999). The introduced wild pig and rusa deer were the most frequently killed mammals in both districts (estimated combined total of 1055 and 442 individuals, respectively), and due to their large size, comprised the bulk of the biomass of all harvested animals (75\% of estimated annual total of 87.9 tonnes) (Table 2). The next most frequently killed animals were two species of bandicoots, but due to their small size, they comprised only a minor proportion of the total wild meat harvest. In contrast, the Northern Cassowary was the fifth most frequently caught animal, yet owing to its large size $(60 \mathrm{~kg})$, it constituted $20 \%$ of the estimated annual total

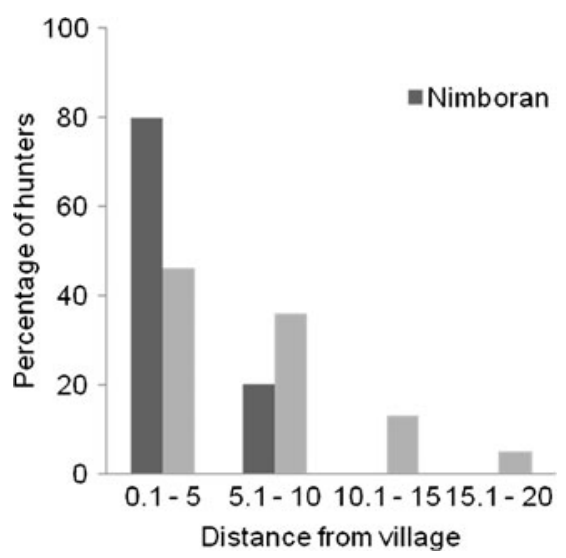

Fig. 2 Distances (in km) walked to hunting sites by hunters from two districts in northeast Papua. No. hunters, 83 (Nimboran) and 63 (Kemtukgresi) 


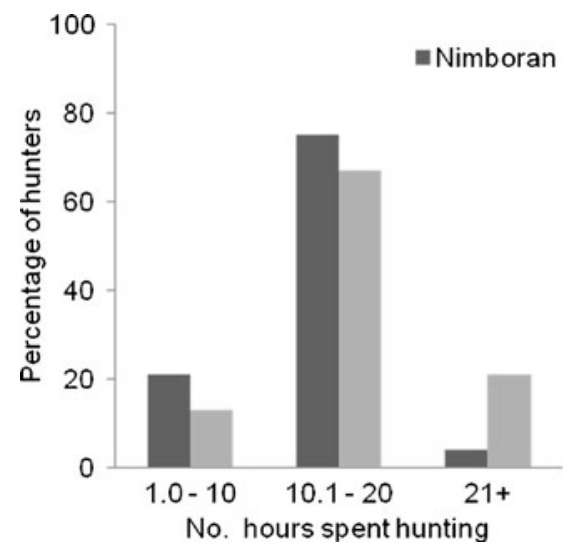

Fig. 3 The amount of time (hrs) devoted to hunting by hunters from two districts in northeast Papua. No. hunters, 84 (Nimboran) and 63 (Kemtukgresi)

biomass (Pangau-Adam and Noske 2010). The remaining mammals, all marsupials, were killed much less frequently, and included the Grizzled Tree-kangaroo $(15.5 \mathrm{~kg})$, Whitestriped Wallaby $(5.5 \mathrm{~kg})$ and three species of cuscuses $(<$ $5 \mathrm{~kg}$; Table 2). Although snakes were rarely captured, the numbers of monitor lizards killed exceeded those of many mammal species (Table 2).

The number of rusa deer killed was significantly higher at Nimboran than at Kemtukgresi, but the converse was true of the number of flying foxes and cuscuses of three species $\left(\chi^{2}=67.29, \mathrm{df}=2, p<0.001\right)$. These differences appeared to be due to the number of hunters hunting each species, as there were no significant differences between the two districts in the number of each species killed by each hunter (Table 3). The number of animals killed per hunter annually varied greatly, ranging from 6 to 48 animals (including birds) in Nimboran, and 3-53 animals in Kemtukgresi. Combining mean estimates of harvest rates from both districts $(n=147)$, an average of 20.1 animals (including birds) were killed by each hunter over 1 year.

\section{Market Analysis and Bushmeat Trade}

During the market surveys, 33 vendors were found selling seven mammal species and two reptile species (Table 4). The number of animals being sold varied over the year, with
Table 2 Approximate annual harvest of mammals and reptiles by Genyem people in two districts (NIM, Nimboran; KGS, Kemtukgresi) of north-east Papua, based on monthly totals reported by 84 hunters in
Nimboran and 63 in Kemtukgresi over 1 year. Birds are quantified separately (Pangau-Adam and Noske 2010)

\begin{tabular}{|c|c|c|c|c|c|c|c|c|c|}
\hline \multirow[t]{2}{*}{ Scientific name } & \multirow[t]{2}{*}{ English name } & \multirow[t]{2}{*}{$\begin{array}{l}\text { Mean weight } \\
(\mathrm{kg})^{\mathrm{a}}\end{array}$} & \multicolumn{2}{|c|}{$\begin{array}{l}\text { Total number } \\
\text { of individual } \\
\text { animals }\end{array}$} & \multicolumn{4}{|c|}{ Total biomass (nearest kg) } & \multirow[t]{2}{*}{$\begin{array}{l}\% \text { total } \\
\text { biomass }\end{array}$} \\
\hline & & & NIM & KGS & NIM & \%biomass & KGS & \%biomass & \\
\hline \multicolumn{10}{|l|}{ Mammals } \\
\hline Sus scrofa & Wild pig & 35.0 & 565 & 490 & 19,775 & 49.9 & 17,150 & 57.2 & 53.1 \\
\hline Cervus timorensis* & Rusa deer & 65.0 & 278 & 164 & 18,070 & 45.7 & 10,660 & 35.6 & 41.3 \\
\hline Echymipera kalubu & Spiny Bandicoot & 1.5 & 246 & 239 & 369 & 0.9 & 359 & 1.9 & 1.04 \\
\hline Echymipera clara & Clara's Bandicoot & 1.3 & 161 & 188 & 209 & 0.5 & 244 & 0.8 & 0.7 \\
\hline Dorcopsis hageni & $\begin{array}{l}\text { White-striped } \\
\text { Wallaby }\end{array}$ & 5.5 & 88 & 57 & 484 & 1.2 & 314 & 1.1 & 1.1 \\
\hline $\begin{array}{l}\text { Dendrolagus } \\
\text { inustus* }\end{array}$ & $\begin{array}{l}\text { Grizzled Tree- } \\
\text { kangaroo }\end{array}$ & 15.5 & 18 & 36 & 279 & 0.7 & 558 & 1.9 & 1.2 \\
\hline $\begin{array}{l}\text { Pteropus } \\
\text { neohibernicus }\end{array}$ & Greater Flying-fox & 1.1 & 31 & 80 & 34 & 0.09 & 88 & 0.3 & 0.2 \\
\hline $\begin{array}{l}\text { Spilocuscus } \\
\text { maculates* }\end{array}$ & Spotted Cuscus & 4.5 & 30 & 49 & 135 & 0.3 & 221 & 0.7 & 0.5 \\
\hline $\begin{array}{l}\text { Phalanger } \\
\text { gymnotis* }\end{array}$ & Ground Cuscus & 3.0 & 22 & 46 & 66 & 0.2 & 138 & 0.5 & 0.3 \\
\hline $\begin{array}{l}\text { Phalanger } \\
\text { orientalis* }\end{array}$ & North-east Cuscus & 2.5 & 15 & 28 & 38 & 0.1 & 70 & 0.2 & 0.2 \\
\hline \multicolumn{10}{|l|}{ Reptiles } \\
\hline Varanus jobiensis & $\begin{array}{l}\text { Peach-throated } \\
\text { monitor }\end{array}$ & 2.0 & 57 & 67 & 114 & 0.3 & 134 & 0.5 & 0.4 \\
\hline Unidentified & Python spp & 25.0 & - & 2 & - & - & 50 & 0.2 & $<0.1$ \\
\hline Total & & & 1,511 & 1,446 & 39,573 & & 29,986 & & 69,559 \\
\hline
\end{tabular}

* nominally protected by Indonesian law (Government Regulation PP RI No. 7 1999)

${ }^{a}$ Weights based on carcasses weighed at market and villages, or from literature (Flannery 1995; Pangkali, pers. comm. 2006) 
Table 3 Comparison of number of mammals and reptiles killed by each hunter over one year in Nimboran $(n=1,511)$ and Kemtukgresi $(n=1,446)$ districts of northeast Papua. Values in parentheses (n) refer to the number of hunters who reported killing at least one animal of the species indicated

Mean \pm standard error of number of animals killed annually per hunter (n)

\begin{tabular}{|c|c|c|c|c|}
\hline Scientific name & Common name & Nimboran & Kemtukgresi & $\mathrm{p}^{*}$ \\
\hline \multicolumn{5}{|l|}{ Mammals } \\
\hline Sus scrofa & Wild pig & $6.89 \pm 0.23(82)$ & $7.78 \pm 0.35(63)$ & 0.81 \\
\hline Cervus timorensis & Rusa deer & $4.68 \pm 0.24(59)$ & $4.97 \pm 0.33(33)$ & 0.50 \\
\hline Echymipera kalubu & Spiny bandicoot & $4.24 \pm 0.25(58)$ & $4.35 \pm 0.30(55)$ & 0.26 \\
\hline Echymipera clara & Clara's Echymipera & $3.35 \pm 0.22(48)$ & $3.92 \pm 0.31(48)$ & 0.42 \\
\hline Dorcopsis hageni & White-striped Wallaby & $5.18 \pm 0.49(17)$ & $5.18 \pm 0.74(11)$ & 0.90 \\
\hline Dendrolagus inustus & Grizzled tree-kangaroo & $4.50 \pm 0.87(4)$ & $5.14 \pm 0.55(7)$ & 0.84 \\
\hline Pteropus neohibernicus & Greater Flying-fox & $15.50 \pm 1.5(2)$ & $8.89 \pm 1.44(9)$ & 0.81 \\
\hline Spilocuscus maculatus & Common Spotted Cuscus & $3.75 \pm 0.45(8)$ & $3.06 \pm 0.31(16)$ & 0.69 \\
\hline Phalanger gymnotis & Ground Cuscus & $3.14 \pm 0.46(7)$ & $3.07 \pm 0.27(14)$ & 0.85 \\
\hline Phalanger orientalis & North-east Common Cuscus & $2.50 \pm 0.43(6)$ & $2.00 \pm 0.26(14)$ & 0.15 \\
\hline \multicolumn{5}{|l|}{ Reptiles } \\
\hline Varanus jobiensis & Peach-throated monitor & $6.11 \pm 0.68(9)$ & $6.7 \pm 0.87(10)$ & 0.94 \\
\hline Unidentified & Python spp & 0 & $1.0 \pm 0.01(2)$ & - \\
\hline
\end{tabular}

* based on Mann-Whitney test

significantly fewer animals during the wet season months of October to February $(t=5.19, \mathrm{df}=9, p<0.001)$. The most frequently sold animals, year-round, were mammals (85\%) including wild pigs, rusa deer, flying foxes, bandicoots, cuscuses, wallabies and tree kangaroos, while birds and reptiles accounted for $12 \%$ and $3 \%$ of total animals sold, respectively (Fig. 4). According to 21 vendors, the majority of consumers asked for the meat of placentals (pig and deer), small marsupials (bandicoots and cuscus) and flying foxes. Monitor lizards (presumably mostly Varanus jobiensis) and large-bodied marsupials (tree-kangaroos and wallabies) were usually consumed by the hunters and their families or in the latter case, if still alive, reared as pets.

Bushmeat was sold either fresh or smoked, and the price ranged from US\$2.20 per animal for small mammals (viz. bandicoots and flying foxes) to US\$50 for some large animals (rusa deer and wild pigs). Surprisingly, pythons fetched higher prices than kangaroos and wallabies (Table 4). Approximately $72 \%$ of the animals offered for sale in the market town $(n=587)$ were brought from the closest district (Nimboran), and the remaining $28 \%$ from Kemtukgresi and other districts further away. The meat of domesticated animals, such as beef and chicken, was rarely offered for sale in the market. Livestock dealers came from Jayapura city, and due to the long distance that animals would have to be transported, they seldom participated in the meat trade in the Genyem region. The meat of domesticated pigs was found occasionally, but few villagers reared these animals for economic benefit or as alternative protein sources. This meat was more expensive than wild meat, because domesticated animals had to be reared at significant cost to the household. Young cuscuses and tree kangaroos were also captured to be reared as pets. However, if the owner needed money, they sold these animals to the immigrant community or offered them in the markets.

Bushmeat was also occasionally sold directly within the villages. This was more common in villages located far from market town, mainly those in Kemtukgresi district. If an animal was not sold quickly within the village, several hunters or their families would smoke the meat, then take it to the market over the following few days. In addition to meat, other animal products were sold, such as insect larvae, and turtle eggs. More than half of the respondents said that they shared

Table 4 Median price of bushmeat from wild game for a whole animal based on market surveys in Genyem town and Nimbokrang market (exchange rate at time of study, US\$1=Rp 9,250)

\begin{tabular}{lll}
\hline Taxon & $\begin{array}{l}\text { Median price } \\
\text { (US\$) }\end{array}$ & $\begin{array}{l}\text { The number of sales } \\
\text { recorded (N) }\end{array}$ \\
\hline Wild pig & 50.0 & 224 \\
Rusa deer & 40.0 & 63 \\
Python & 22.5 & 3 \\
Tree-Kangaroo & 12.5 & 8 \\
Wallaby & 7.0 & 14 \\
Cuscus & 5.8 & 15 \\
Monitor lizard & 3.5 & 13 \\
Bandicoot & 2.9 & 124 \\
Flying fox & 2.9 & 123 \\
\hline
\end{tabular}


Fig. 4 The number of wild animals sold each week in Genyem and Nimbokrang markets, July 2005 to June 2006. It was not possible to sample the markets in April 2006 due to civil unrest in the towns

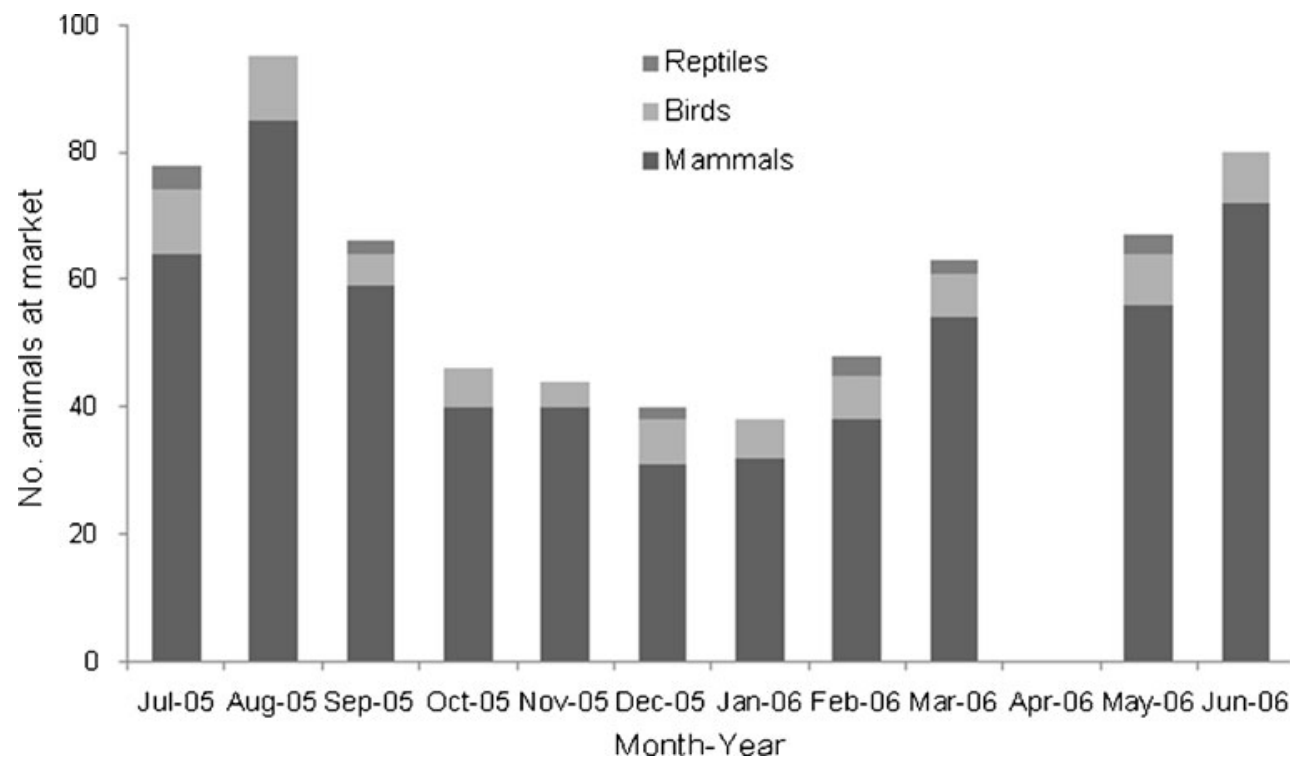

bushmeat with relatives if it was not completely sold in the market or village.

\section{Household Meal Analysis}

Wild meat appeared to be the most prevalent source of animal protein in the seven villages sampled. From 546 records of meals, it was found that the percentage of meals containing wild meat $(51.1 \%)$ was greater than those containing fish $(17.4 \%)$, domestic animals $(13.7 \%)$, vegetables $(16.0 \%)$ and/or other food items (1.8\%). The composition of meals did not appear to differ between the two districts but sample sizes were small (four villages in Nimboran and three in Kemtukgresi) for any statistical analysis. Subsistence hunters hunted to satisfy the protein needs of their families, while commercial hunters captured and sold wild animals for cash. However, heads, legs and intestines of killed animals were typically removed $(\sim 1-5 \mathrm{~kg}$ per animal) for family consumption prior to transporting the prime meat cuts to the market or selling it in the village.

\section{Discussion}

Traditionally, hunting was an extremely important livelihood activity in northeast Papua because it provided the majority of animal protein for families. Prior to western contact, Genyem people would have hunted only for subsistence purposes. The introduction of a cash market economy, combined with rapid urban and infrastructure development in northeast Papua and transmigration programmes, however, have brought a significant change in hunting purposes and practices in this region. In our study, only $26 \%$ of interviewed hunters declared that they hunted mainly for subsistence purposes, showing that there has been a marked shift from local-level subsistence hunting for meat consumption towards more intensive commercial hunting. Consequently, Genyem people now view wildlife as a significant source of income. Family heads often viewed hunting as a way to fulfil their family's livelihood needs and to provide the financial support needed for sending their children to school. Although most hunters also grew crops, hunting was viewed as a way to obtain immediate cash throughout the year, as opposed to the possibly higher but only seasonal economic benefits from agriculture.

Mack and West (2005) contrast the use of game as "bushmeat", where there is a market for this meat and trade items, with hunting in Papua-New Guinea, where there is little or no such market, and where the animals are used mainly as a source of "wildmeat.". Using their criteria, however, the use of game at our study sites in northeast Papua qualifies as "bushmeat", rather than "wildmeat (Table 5). Commercial hunters invariably sold the valuable parts of harvested animals, but consumed the less valuable parts within their families. Drivers of demand also included requirements for ceremonial events. Thus the rationale for hunting by Genyem people, and likely other ethnic groups in Papua, differs dramatically from that reported in PapuaNew Guinea to date.

At a fundamental level these differences reflect the vastly different political and social development of the two sides of the island since the transfer of former Irian Jaya from one colonial power (Netherlands) to another (Indonesia) during the 1960s (Timmer 2007), and of PNG from Australian territory to self-government in 1975. In the case of Papua, President Suharto's 'New Order' led to the emergence of a well-established cash economy in which industries such as logging and plantation agriculture (oil palm, cocoa) provide employment for many transmigrants but only a small number of indigenous people (Boissière and Purwanto 2007). This economy has also led to a rampant and ongoing illegal 
trade in live birds although the participants are largely Indonesian transmigrants and few indigenous hunters are involved (Pangau-Adam and Noske 2010).

\section{Hunting Methods and Practices}

In our study, hunting with bow-and-arrow and trapping with snares were the predominant hunting techniques, both used in over $70 \%$ of hunts. Bow and arrows are the traditional method of killing game throughout New Guinea (e.g., Majnep and Bulmer 1977). In the Crater Mountain Wildlife Management Area (CMWMA) of the Eastern Highlands of Papua-New Guinea, about a half of the kills were made with bow and arrows, whereas a relatively small proportion (c. $10 \%$ ) of kills involved the use of traps (Mack and West 2005). The greater use of traps in Papua may be due to influence of transmigrants who introduced the use of cable snares, as well as the larger prey targeted. Snare trapping can result in high rates of wasted captures (Lee 2000; Noss 2000). In our study region, most hunters were well aware of how long animals could survive in a snare, yet many animals still died in snares long before the hunter arrived because hunters did not patrol snare lines on a daily basis. Air rifles were introduced to the trading town by transmigrants from Java and South Sulawesi. Both local people and transmigrant settlers use this weapon to hunt Birds of Paradise, stuffed specimens of which fetch a similar price to wild pig and deer meat. Due to the high cost of air rifles and cartridges, however, relatively few hunters used this method of hunting.

The fact that hunters in Kemtukgresi hunted for longer and travelled further than those in Nimboran may be related to the lack of logging activities in Kemtukgresi district, as logging roads in the former district probably provided ready access to more sites within $5 \mathrm{~km}$ of the villages. Despite marked disparities between our study area and CMWMA in human population densities (6.0 6.6 persons per $\mathrm{km}^{2}$ and $1.8 \mathrm{~km} 2$, respectively), and ecosystem diversity, the mean distances travelled by hunters are remarkably similar (1.6-5.5 km in CMWMA,
Mack and West 2005; 4.4-7.4 km in Nimboran and Kemtukgresi, respectively).

Factors Influencing Target Species and Hunting Pressure

The main hunting targets in this study were the introduced wild pig and rusa deer, apparently because of the large amount of meat each individual provided. Although archaeologists have speculated that the wild pig has been in Papua for 6,000 to 12,000 years, it seems likely that they arrived about 3,600 years BP (Diamond 1997), and they are now widespread throughout the island. The rusa deer, on the other hand, was introduced from Java only as recently as 1928 and its known range is restricted to the south coastal plains (Trans-Fly region), as well as northwest and northeast Papua (Flannery 1995; Pattiselanno and Arobaya 2009). The availability of rusa deer in the study area, therefore, constitutes another important difference between this study and previous studies of hunting practices, all of which emanate from PNG. Likewise, in the contiguous areas of Wasur National Park, southeast Papua, and Tonda Wildlife Management Area, south-western PNG, where the rusa deer is causing large-scale damage to swamps and grasslands (Bowe et al. 2007) there is widespread deer poaching to provide meat for the nearby township of Merauke, on the Papuan side of the border, whereas on the PNG side the deer are not utilized by the local population apart from some trophy hunting (Bowe 2000; Stronach 2000).

In the CMWMA of PNG, large animals comprised a slightly lower percentage (58 \%) of the total biomass harvested by hunters than in the present study $(75 \%)$, wild pig making the greatest contribution (31\%) and cassowary the remainder (27\%) (Mack and West 2005). The most frequently killed animals in CMWMA were small birds, cuscus and bandicoots, which comprisied $20 \%, 16 \%$ and $11 \%$ of all individuals, respectively, although only cuscus made a significant contribution (15\%) to the total biomass of prey harvested (Mack and West 2005). Data from this and eight other hunting studies indicated that among medium-sized
Table 5 Differences between "bushmeat" and "wildmeat" (after Mack and West 2005), and hunting characteristics in northeast Papua, as observed in this study

* prey not legally owned by hunters/landowners

${ }^{+}$with appropriate law enforcement

\begin{tabular}{llll}
\hline Attribute & Bushmeat & Wildmeat & This study \\
\hline Hunter eats prey & No & Yes & Partly \\
Prey killed on land owned by the hunter & No & Yes & no* \\
Prey transported significant distances & Yes & No & Yes \\
Prey sold for cash & Yes & No & Yes \\
Middlemen between hunter and consumer & Yes & No & Yes \\
Can be regulated by central governments & Yes & No & yes \\
Demand driven by market forces & Yes & No & partly \\
Demand increases with consumers' personal wealth & Yes & No & yes
\end{tabular}


mammals, cuscus and bandicoots were the major source of game throughout PNG, accounting for $42 \%$ and $26 \%$ of captures, respectively, although the proportions of these two taxa were strongly negatively correlated, suggesting that they replaced each other as the principal game in different areas (Cuthbert 2010). However there was no evidence of this effect among the two districts we studied in northeast Papua, with the estimated annual harvest of bandicoots being 5-8 times higher than that of cuscus (Table 2).

Hunting pressure on a given targeted species in northeast Papua appears to be a function of ecological, cultural and economic factors. Important ecological factors are the habitat preferences, behaviour and reproductive rates of the animals. Most of the primarily hunted species are habitat generalists. Wild pigs, flying foxes and bandicoots are known to survive in a range of habitats, including highly disturbed ones (Petocz 1994; Flannery 1995). As shown in other studies (Bodmer 1994; Robinson and Bennett 2000), differences in harvest rates between species in this study probably partly reflect the ease with which different species can be captured. Rusa deer and wild pig are relatively easy to hunt because they leave clear trails in the forest along which snares can be set. Bandicoots are among the most frequently killed animals because they are abundant in secondary forest and mixed gardens next to and even inside villages, and their trails are easy to recognize.

Religious and cultural factors also influence hunting practices among Genyem people. For example, traditionally certain animals could be only hunted by the clan leaders, while others could not be killed by hunters at certain times (e.g. when their wives were pregnant). However there is some evidence that traditional Genyem beliefs are breaking down as some species that were once considered taboo (e.g. cassowaries, certain birds-of-paradise), are now hunted (Pangau-Adam and Noske 2010). Wild animals, mainly pigs, are still occasionally killed for community festivals and religious ceremonies. To provide sufficient wildmeat for such events, clans hunted as a group. When a large amount of meat is required for a cultural event, wildmeat is the most accessible source in rural areas (Pattiselanno 2006). Both wild and domesticated pigs play an important role for culture and traditional economies in New Guinea (Majnep and Bulmer 1977; Flannery 1995), and are a major source of wildmeat for traditional Southeast Asian peoples (Alvard 2000; Bennett et al. 2000). In this study many hunters (91\%) also targeted wild pigs because the number of pig jaws they collected was traditionally a sign of their social status.

The Importance of Commercial Hunting in North-East Papua

We believe that the critical factor explaining target species preferences in our study area is the anticipated economic benefits. The most targeted species for commercial hunting were the largest-bodied (viz. wild pigs, rusa deer and cassowaries; all $>30 \mathrm{~kg}$ ), as these animals provided more meat for sale and generated more economic benefits for hunters' households. The anticipated financial gain for a hunter from the sale of three such animals (US\$35-50 each) is approximately equivalent to the monthly salary of a locally employed permanent worker. High harvest rates of largebodied diurnal animals have been reported from studies in other tropical forests (Colell et al. 1994; Bodmer 1994). In this study, differences in harvest rates of target species also appear to be influenced by market demand and consumer preferences for particular bushmeat. The meat of rusa deer, for example, was preferred by transmigrants over the meat of tree-kangaroos and wallabies, which was preferred by local people, according to interviewed hunters and market vendors. That more rusa deer were killed in Nimboran than Kemtukgresi appears to be due to a greater number of hunters hunting this species in the former district, probably because of their popularity as bushmeat. In contrast, cuscuses and flying foxes were killed by fewer hunters in Nimboran than in Kemtukgresi possibly because they were less popular as bushmeat.

Several lines of evidence support our prediction that the extent to which villagers engaged in commercial bushmeat trade is related to the distance of their villages from the major market. At Genyem market town, $72 \%$ of the animals offered for sale had been brought from villages in the closest district (Nimboran), and the remainder from Kemtukgresi and other districts further away. Although a similar percentage of hunters in the two districts considered themselves professional hunters, only $5 \%$ of hunters in Nimboran district declared that they hunted primarily for subsistence, as compared to $38 \%$ of hunters in Kemtukgresi.

Lack of alternative economic opportunities may be a driving force for the commercial hunting reported in this study. There are crop farming systems and small-scale cocoa plantations in the region, but villagers seem less successful in pursuing this activity than the transmigrants, due to their lack of requisite knowledge and skills (see for example, Timmer 2007). Logging companies also appear to prefer to employ non-indigenous peoples. Although many hunters were engaged in subsistence farming of maize, manioc, sweet potatoes and other vegetables, they felt that hunting could provide them with higher economic benefits. Since the market in Genyem town developed and is offering wild meat for sale three times per week, hunters have increased their efforts to harvest more wild animals in order to increase their profits.

Conservation and Sustainable Utilisation of Hunted Species

Despite the high hunting pressure on bandicoots in our study, hunters claimed that populations of these animals remained stable. This suggests that these animals have high reproductive 
rates, consistent with the ability of females to raise large litters of up to 9 pouch young year-round (Flannery 1995). Indeed Cuthbert (2010) concluded that bandicoots (and ringtail possums) were the only group of medium-sized mammals that could provide a sustainable harvest in PNG, because of their high population densities, and high intrinsic rate of increase.

Nevertheless most harvested animal species in the study area are endemic to New Guinea, and three of the target species (Grizzled Tree-kangaroo, Northern Cassowary and Victoria Crowned Pigeon) are classified as Vulnerable by IUCN (2010). Although five of the ten mammal species targeted by hunters in our study area are theoretically protected by Indonesian law (Table 2), about $90 \%$ of the interviewed hunters and villagers claimed that they were unaware of any legislation governing the protection of wild animals. Given this lack of local awareness about wildlife legislation, the lack of enforcement of laws pertaining to hunting and wildlife trade, and the obvious involvement of Indonesian transmigrants and the military in the latter (Frazier 2007), it is hardly surprising that hunting of 'protected' animals continues among indigenous peoples.

A comparison of the reported rates of harvesting and estimated rates of production in Papua-New Guinea indicated that tree-kangaroos and cuscus are harvested unsustainably, whereas the hunting of bandicoots was lower than production levels, suggesting that bandicoots could potentially provide a sustainable source of protein, in preference to scarcer and slower-breeding larger species (Cuthbert 2010). Alternatively, ongoing depletion of the latter species may create a substantial financial burden in areas where people have the least nutritious diets and the poorest health care (Mack and West 2005).

Since hunting is crucial for Genyem people to meet their livelihood and customary needs, we propose a socially sensitive approach to wildlife management rather than a ban on hunting. In order to effectively manage hunting, it is useful to distinguish between the relative significance of hunting for subsistence and commercial trade (Rao et al. 2005). A number of wild animals such as tree-kangaroos, wallabies and reptiles in the Genyem area are only harvested to supply protein for local people. To maintain wild populations of these and other economically or culturally valuable animal species, such as cassowaries and cuscuses, hunters ought to be encouraged to hunt non-indigenous species (i.e., wild pig and rusa deer) that have a negative impact on natural habitats, and/or native species that have high reproductive rates, such as the bandicoots (Bodmer 1994; Fitzgibbon et al. 1995; Cuthbert 2010). Education programmes are essential to raise awareness about maintaining populations of threatened species among both local communities and government, at both local and regional levels (Riley 2002). In addition, domesticated pigs could be advocated as an alternative source of protein with government support for establishing pig farms. Whilst alternative sources of income, such as farming cash crops (e.g. cocoa and coffee), may reduce hunting pressure on wildlife, such activities could also result in increased habitat destruction through the clearing of forests to allow planting of such crops.

Acknowledgements We are grateful to the Genyem communities and district leaders for their support of this research. The Wildlife Conservation Society and Rufford Foundation provided financial support, without which this research would not have been possible. Many thanks to Supeni Sufaati, Katrin Mahuse, Elias Buiney and Pak Dance for assistance in the field and sincere thanks to Christos Astaras for the helpful comments on drafts of this article.

Open Access This article is distributed under the terms of the Creative Commons Attribution License which permits any use, distribution, and reproduction in any medium, provided the original author(s) and the source are credited.

\section{References}

Alvard, M. (2000). The impact of traditional subsistence hunting and trapping on prey populations: Data from Wana Horticulturalists of upland Central Sulawesi, Indonesia. In Robinson, J. G., and Bennett, E. L. (eds.), Hunting for Sustainability in Tropical Rainforests. Columbia University Press, New York, pp. 214-230.

Alvard, M. S., Robinson, J. G., Redford, K. H., and Kaplan, H. (1997). The Sustainability of Subsistence Hunting in the Neotropics. Conservation Biology 11: 977-982.

Beehler, B. M., Pratt, T. K., and Zimmerman, D. A. (1986). Birds of New Guinea. Princeton University Press, Princeton, USA.

Bennett, E. L., and Dahaban, Z. (1995). Wildlife responses to disturbance in Sarawak and their implication for forest management. In Primack, R. B., and Lovejoy, T. E. (eds.), Ecology, Conservation and Management of Southeast Asian Rainforest. Yale University Press, London, pp. 66-86.

Bennett, E. L., Nyaoi, A. J., and Sompud, J. (2000). Saving Borneo's bacon: the sustainability of hunting in Sarawak and Sabah. In Robinson, J. G., and Bennett, E. L. (eds.), Hunting for Sustainability in Tropical Rainforests. Columbia University Press, New York, USA, pp. 305-324.

Birdlife International (2000). Threatened Birds of the World. BirdLife International, Cambridge, UK.

Bodmer, R. E. (1994). Managing wildlife with local communities in the Peruvian Amazon: The case of the Reserva Comunal Tamshiyacu-Tahuayo. In Western, D., Wright, R. M., and Strum, S. (eds.), Natural Connections. Island Press, Washington DC., USA, pp. 113-134.

Boissière, M., and Purwanto, Y. (2007). The agricultural systems of Papua. In Marshall, A. J., and Beehler, B. M. (eds.), The Ecology of Papua, Part Two. The Ecology of Indonesia Series, Vol. VI. Periplus Editions, Singapore, pp. 1125-1148.

Bowe, M. (2000). Development of regional synergies between Northern Australia and the Trans-Fly region of Indonesia and Papua New Guinea. In Russell-Smith, J., Hill, G., Djoeroemana, S., and Myers, B. (eds.), Fire and Sustainable Agricultural and Forestry Development in Eastern Indonesia and Northern Australia. Proceedings of an international workshop held at Northern Territory University, Darwin, Australia, 13-15 April 1999. Australian Centre for International Agricultural Research, Canberra, ACT, pp. 138-142. 
Bowe, M., Stronach, M., and Bartalo, R. (2007). Grassland and savanna ecosystems of the Trans-Fly, southern Papua. In Marshall, A. J., and Beehler, B. M. (eds.), The Ecology of Papua, Part Two. The Ecology of Indonesia Series, Vol. VI. Periplus Editions, Singapore, pp. 1054-1063.

Colell, M., Maté, C., and Fa, J. E. (1994). Hunting Among Moka Bubis in Bioko: Dynamics of Faunal Exploitation at the Village Level. Biodiversity and Conservation 3: 939-950.

Conservation International (CI). (1999). The Irian Jaya biodiversity conservation priority-setting workshop', Biak, 7 -12 January 1997. Final Report, Washington, D.C., USA.

Cuthbert, R. (2010). Sustainability of Hunting, Population Densities, Intrinsic Rates of Increase and Conservation of Papua New Guinean Mammals: A Quantitative Review. Biological Conservation doi:10.1016/j.biocon.2010.04.005.

Diamond, J. M. (1997). Guns, Germs, and Steel: The Fates of Human Societies. W.W. Norton \& Company, New York, London.

Dwyer, P. D., and Minnegal, M. (1991). Hunting in Lowland, Tropical Rain Forest: Towards a Model of Non-agricultural Subsistence'. Human Ecology 19: 187-212.

Fitzgibbon, C. D., Mogaka, H., and Fanshawe, J. H. (1995). Subsistence Hunting in Arabuko-Sokoke Forest, Kenya and its Effects on Mammal Populations. Conservation Biology 9: 1116-1126.

Flannery, T. F. (1994). The Fossil Land Mammal Record of New Guinea: A Review. Science in New Guinea 20: 39-48.

Flannery, T. F. (1995). Mammals of New Guinea. Reed Books, Australia.

Frazier, S. (2007). Threats to biodiversity. In Marshall, A. J., and Beehler, B. M. (eds.), The Ecology of Papua, Part Two. The Ecology of Indonesia Series, Vol. VI. Periplus Editions, Singapore, pp. 1199-1229.

Frith, C. B., and Beehler, B. M. (1998). The Birds of Paradise. Oxford University Press, Oxford.

Healey, C. (1989). The Man Who Became a Bird of Paradise: Myth in the Papua New Guinea Highlands. Northern Perspective 12: 24-30.

Healey, C. (1993). Folk Taxonomy and Mythology of Birds of Paradise in the New Guinea Highlands. Ethnology 32: 19-34.

IUCN. (2010). IUCN Red List of Threatened Species. Version 2010.4. [online] URL: http://www.iucnredlist.org. Downloaded on 30 April 2011.

Johnson, A., Bino, R., and Igag, P. (2004). A Preliminary Evaluation of the Sustainability of Cassowary (Aves: Casuariidae) Capture and Trade in Papua New Guinea. Animal Conservation 7: 129-137.

King, C. E., and Nijboer, J. (1994). Conservation Considerations for Crowned Pigeon, GENUS GOURA. Oryx 28: 22-30.

Kwapena, N. (1984). Traditional Conservation and Utilization of Wildlife in Papua New Guinea. The Environmentalist 4: 22-26.

Lee, R. J. (2000). Impact of subsistence hunting in North Sulawesi, Indonesia and conservation options. In Robinson, J. G., and Bennett, E. L. (eds.), Hunting for Sustainability in Tropical Rainforest. Columbia University Press, New York, pp. 455-472.

Mack, A. L., and West, P. (2005). Ten thousand tonnes of small animals: wildlife consumption in Papua New Guinea, a vital resource in need of management. Resource Management in Asia-Pacific Working Paper No. 61. Resource Management in Asia-Pacific Program, Research School of Pacific and Asian Studies, Australian National University, Canberra.

Majnep, I. S., and Bulmer, R. (1977). Birds of my Kalam Country. Aukland University Press, Aukland.

Majnep, I. S., and Bulmer, R. (2007). Animals the Ancestors Hunted: An Account of the Wild Animals of the Kalam Area. Crawford House Publishing, Adelaide, Australia, Papua New Guinea.
Menzies, J. (1991). A Handbook of New Guinea Marsupials \& Monotremes. Kristen Pres Inc Madang, PNG.

Noss, A. (2000). Cable snares and nets in the Central African Republic. In Robinson, J. G., and Bennett, E. L. (eds.), Hunting for Sustainability in Tropical Rainforests. Columbia University Press, New York, pp. 455-472.

Pangau-Adam, M., and Noske, R. A. (2010). Wildlife hunting and bird trade in north-east Papua (Irian Jaya), Indonesia. In Tidemann, S., Gosler, A., and Gosford, R. (eds.), Ethno-Ornithology: Birds, Indigenous Peoples, Culture and Society. Earthscan, London, pp. $73-86$

Pattiselanno, F. (2006). The Wildlife Hunting in Papua, Indonesia. Biota 11: 59-61.

Pattiselanno, F., and Arobaya, S. Y. S. (2009). Grazing Habitat of the Rusa Deer (Cervus timorensis) in the Upland Kebar, Manokwari. Biodiversitas 10: 134-138.

Petocz, R. (1989). Conservation and Development in Irian Jaya. E.J. Brill. Leiden Princeton University Press, New Jersey.

Petocz, R. (1994). Mamalia Darat Irian Jaya (Terrestrial Mammals of Irian Jaya). Gramedia Pustaka Utama, Jakarta, Indonesia.

Rao, M., Myint, T., Zaw, T., and Htun, S. (2005). Hunting Patterns in Tropical Forests Adjoining the Hkakaborazi National Park, North Myanmar. Oryx 39: 292-300.

Richards, S. J., and Suryadi, S. (2000). A Biodiversity Assessment of Yongsu - Cyclop Mountains and the Southern Mamberamo basin, Papua. RAP Bulletin of Biological Assessment 25. Conservation International, Washington DC.

Riley, J. (2002). Mammals on the Sangihe and Talaud Islands, Indonesia, and the Impact of Hunting and Habitat Loss. Oryx 36: 288 296.

Robinson, J. G., and Bennett, E. L. (2000). Carrying capacity limits to sustainable hunting in tropical forests. In Robinson, J. G., and Bennett, E. L. (eds.), Hunting for Sustainability in Tropical Rainforests. Columbia University Press, New York, pp. 13-30.

Robinson, J. G., and Redford, K. H. (1991). Sustainable Harvest of Neotropical Forest Mammals. In Robinson, J. G., and Redford, K. H. (eds.), Neotropical Wildlife Use and Conservation. University of Chicago Press, Chicago, pp. 415-429.

Sillitoe, P. (2001). Hunting for Conservation in Papua-New Guinea Highlands. Ethnos 66: 365-393.

Stattersfield, A. J., Crosby, N. J., Long, A. G., and Wege, C. (1998). Endemic Bird Areas of the World. Priority Areas for Biodiversity Conservation. Birdlife Conservation Series no. 7. Birdlife International, Cambridge.

Stronach, N. (2000). Fire in the Trans-Fly savanna, Irian Jaya/PNG. In Russell-Smith, J., Hill, G., Djoeroema, S., and Myers, B. (eds.), Fire and Sustainable Agricultural and Forestry Development in Eastern Indonesia and Northern Australia. Proceedings of an international workshop held at Northern Territory University, Darwin, Australia, 13-15 April 1999. Australian Centre for International Agricultural Research, Canberra, ACT, pp. 90-93.

Suryadi, A., Wijayanto, A., and Cannon, J. B. (2007). Conservation Laws, regulations, and legislation in Indonesia, with special reference to Papua. In Marshall, A. J., and Beehler, B. M. (eds.), The Ecology of Papua, Part Two. The Ecology of Indonesia Series, Vol. VI. Periplus Editions, Singapore, pp. 1276-1310.

Timmer, J. (2007). A brief social and political history of Papua, 1962 2005. In Marshall, A. J., and Beehler, B. M. (eds.), The Ecology of Papua, Part Two. The Ecology of Indonesia Series, Vol. VI. Periplus Editions, Singapore, pp. 1098-1124.

Wilkie, D., Shaw, E., Rotberg, F., Morelli, G., and Auzel, P. (2000). Roads, Development, and Conservation in the Congo Basin. Conservation Biology 14: 1614-1622. 